\title{
Inappropriate Audible Prompt/Feedback
}

National Cancer Institute

\section{Source}

National Cancer Institute. Inappropriate Audible Prompt/Feedback. NCI Thesaurus. Code C63094.

Problem with audible messages which do not guide a device user to the correct action. 